\title{
Original Device
}

National Cancer Institute

\section{Source}

National Cancer Institute. Original Device. NCI Thesaurus. Code C54644.

A new, unused single-use device. 